\title{
Programmed cell death in the marine cyanobacterium Trichodesmium mediates carbon and nitrogen export
}

\author{
Edo Bar-Zeev ${ }^{1,3}$, Itamar Avishay ${ }^{1}$, Kay D Bidle ${ }^{2}$ and Ilana Berman-Frank ${ }^{1}$ \\ ${ }^{1}$ Mina and Everard Goodman Faculty of Life Sciences, Bar-Ilan University, Ramat Gan, Israel and \\ ${ }^{2}$ Environmental Biophysics and Molecular Ecology Group, Institute of Marine and Coastal Sciences, \\ Rutgers University, New Brunswick, NJ, USA
}

\begin{abstract}
The extent of carbon $(\mathrm{C})$ and nitrogen $(\mathrm{N})$ export to the deep ocean depends upon the efficacy of the biological pump that transports primary production to depth, thereby preventing its recycling in the upper photic zone. The dinitrogen-fixing (diazotrophic) Trichodesmium spp. contributes significantly to oceanic $\mathbf{C}$ and $\mathbf{N}$ cycling by forming extensive blooms in nutrient-poor tropical and subtropical regions. These massive blooms generally collapse several days after forming, but the cellular mechanism responsible, along with the magnitude of associated $\mathrm{C}$ and $\mathrm{N}$ export processes, are as yet unknown. Here, we used a custom-made, 2-m high water column to simulate a natural bloom and to specifically test and quantify whether the programmed cell death (PCD) of Trichodesmium mechanistically regulates increased vertical flux of $\mathrm{C}$ and $\mathrm{N}$. Our findings demonstrate that extremely rapid development and abrupt, PCD-induced demise (within 2-3 days) of Trichodesmium blooms lead to greatly elevated excretions of transparent exopolymers and a massive downward pulse of particulate organic matter. Our results mechanistically link autocatalytic PCD and bloom collapse to quantitative $\mathrm{C}$ and $\mathrm{N}$ export fluxes, suggesting that PCD may have an impact on the biological pump efficiency in the oceans.
\end{abstract}

The ISME Journal (2013) 7, 2340-2348; doi:10.1038/ismej.2013.121; published online 25 July 2013

Subject Category: Geomicrobiology and microbial contributions to geochemical cycles

Keywords: programmed cell death; bloom; Trichodesmium; carbon and nitrogen export flux

\section{Introduction}

Trichodesmium surface blooms (hereafter, referred to as 'blooms') were reported and described near the Torres Straits as 'sea-sawdust' by Captain James Cook and Sir Joseph Banks on the Endeavor's first voyage (Banks, 1770), and near the Abrolhos Islands (east of Bahia, Brazil) in 1832 by Charles Darwin (Darwin, 1909). More recently, remote sensing has revealed the scope of these massive blooms in the subtropical and tropical oceans, extending over $5.4 \times 10^{6} \mathrm{~km}^{2}$ (Subramaniam et al., 1999; Westberry and Siegel, 2006) and consisting of up to $1.2 \times 10^{7}$ cells ${ }^{-1}$ (Capone et al. 1998; Lugomela et al., 2002; Rodier and Le Borgne, 2008, 2010). These blooms develop swiftly and are characterized by high rates of $\mathrm{CO}_{2}$ and $\mathrm{N}_{2}$ fixation, up to $640 \mathrm{pg} \mathrm{C}$ per cell per

Correspondence: E Bar-Zeev, Department of Chemical and Environmental Engineering, Yale University, 9 Hillhouse, New Haven, CT 06520, USA.

E-mail: edobarzeev@gmail.com

${ }^{3}$ Current address: Department of Chemical and Environmental Engineering, Yale University, New Haven, CT 06520, USA.

Received 7 April 2013; revised 10 June 2013; accepted 15 June 2013; published online 25 July 2013 day and $29 \mathrm{pg} \mathrm{N}$ per cell per day, respectively, as well as rapid doubling times ( $\sim 2.6$ day) (Capone et al., 1998; Rodier and Le Borgne, 2008, 2010; Luo et al., 2012). The elicitors and signals causing these rapid surface-bloom formations of Trichodesmium are still vague (Berman-Frank et al., 2007; Rodier and Le Borgne, 2010; Bergman et al., 2012).

Notably, these massive Trichodesmium blooms often collapse abruptly (within 3-5 days), with mortality rates paralleling bloom development rates (Rodier and Le Borgne, 2008, 2010; Bergman et al., 2012) and with different processes (not necessarily mutually exclusive in natural populations) being implicated in their termination. Bloom crashes may result from viral lysis (Hewson et al., 2004) or autocatalytic programmed cell death (PCD), which is induced by nutrient (iron ( $\mathrm{Fe}$ ) starvation) or high light (oxidative) stress in both laboratory and natural populations (Berman-Frank et al., 2004, 2007). PCD has indeed been well documented in a variety of diverse phytoplankton lineages including bloom formers like Trichodesmium (Berman-Frank et al., 2004; Bidle and Falkowski, 2004), implicating it as an important feature of algal ecophysiology. However, the nature and mechanistic controls of 
PCD in phytoplankton are not well understood and, moreover, the consequences of this cellular process on ecosystem and biogeochemical dynamics are virtually unexplored.

Indeed, the fate and quantitative contribution of Trichodesmium blooms to the vertical export or recycling of newly fixed nitrogen (N) and carbon (C) in the ocean following bloom collapse is poorly studied (Mulholland, 2007; Bergman et al., 2012), despite its global-scale importance (62-137 Tg N per year and 2.1-18 Tg C per year) (Luo et al., 2012). Trichodesmium may release up to $50-80 \%$ of recently fixed $\mathrm{N}_{2}$ in natural communities and cultures as dissolved organic $\mathrm{N}$ and ammonium $\left(\mathrm{NH}_{4}^{+}\right.$) (Mulholland, 2007). Low $\delta^{15} \mathrm{~N}$ of exported material collected from the HOTS and BATS time series stations indicates that recently fixed $\mathrm{N}$ is transferred out of the euphotic zone (Karl et al., 2002), although Trichodesmium is rarely recovered in sediment traps and is only grazed by three representatives of the Miraciidae family of pelagic harpacticoid copepods, mostly by Macrosetella gracilis (O’Neil, 1998).

Our previous findings indicate that PCD in Trichodesmium may trigger rapid sinking due to concomitant internal cellular degradation, vacuole loss and increased production of extracellular polysaccharide aggregates, operationally defined as transparent exopolymeric particles (TEPs) (Berman-Frank et al., 2004, 2007). In the present study, we used a customized, experimental water column to specifically test and quantify for the first time whether PCD-induced-bloom demise of Trichodesmium mechanistically regulates increased vertical fluxes of $\mathrm{C}$ and $\mathrm{N}$, thereby facilitating its rapid export from surface waters to depth.

\section{Materials and methods}

Experimental setup

Triplicate experiments were conducted with Fe-free medium to determine the relationship between PCD-induced bloom termination, and $\mathrm{C}$ and $\mathrm{N}$ export fluxes. In all experiments, measurements were performed to assess culture state (cell abundance and Chl a), PCD induction (caspase-specific activity and metacaspase gene expression) and organic export (total organic C (TOC), particulate organic C (POC), dissolved organic C (DOC), TEP and particulate organic N (PON) levels). Prior to surface-bloom induction, Trichodesmium erythraeum IMS101 was cultivated as 'pre-bloom' exponential-phase batch cultures $\left(0.5 \times 10^{6}\right.$ cells $\mathrm{ml}^{-1}$ ) in a 10-l air-bubbled YBC II medium (Chen et al., 1996) at $25^{\circ} \mathrm{C}$ with a $12: 12$ light/dark cycle at $\sim 80 \mathrm{mmol}$ quanta $\mathrm{m}^{-2} \mathrm{~s}^{-1}$. Although Trichodesmium IMS101 stock cultures were not axenic, cohabitating bacteria accounted for $<1 \%$ of the total biomass during exponential growth (as determined by epifluorescence microscopy counts). All culture transfers were performed ascetically and media in water columns was kept sterile throughout the experiments.

Experiments were all conducted in a custommade water column $(200 \mathrm{~cm}$ high, $13.8 \mathrm{~cm} \mathrm{( \emptyset )}$ cylinder, five sampling ports) that was fabricated to resemble and model a water column (Figure 1, Supplementary Figure S1). The cylinder was kept in dark (using a black-out jacket) except for surface illumination in a 12:12 light:dark cycle at $\sim 600$ mmol quanta $\mathrm{m}^{-2} \mathrm{~s}^{-1}$. The custom-made external halogen light source was positioned $0.5 \mathrm{~m}$ from the surface water column, illuminating fixture by a fiber optic cord to avoid any thermal stress. Experiments were set by pumping $30 \mathrm{l}$ of sterile YBC II (Fe-free) medium from the bottom of the cylinder using a peristaltic pump (Masterflex 6600, Cole-Parmer Instruments, Vernon Hills, IL, USA). After the water column was filled with YBC II, $\sim 600$ million Trichodesmium cells (from the 'pre-blooming' batch culture) were poured from the top. Each experiment was conducted over 5 days and five depths were routinely sampled: surface layer $(0.5 \mathrm{~cm}), 50,100,150$ and $200 \mathrm{~cm}$ deep. All

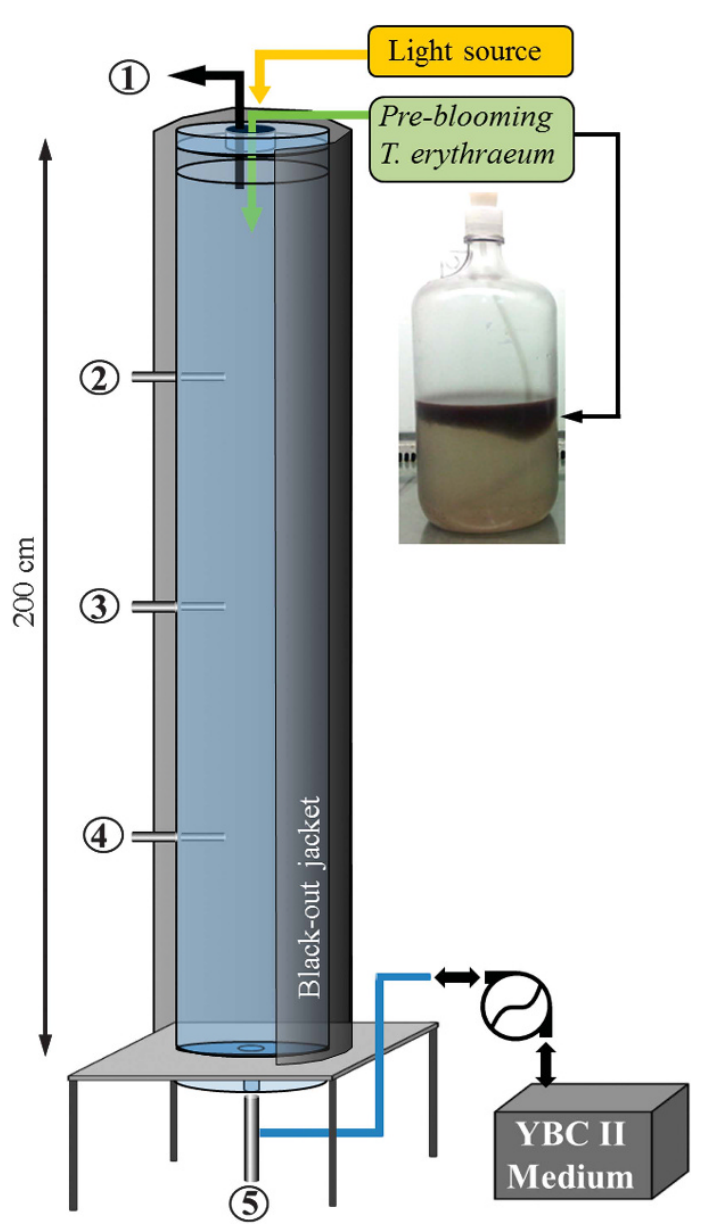

Figure 1 Schematic overview of the experimental water column setup. The numbers correspond to sampling depths: 1 (surface), $2(50 \mathrm{~cm}), 3(100 \mathrm{~cm}), 4(150 \mathrm{~cm})$ and 5 (bottom, $200 \mathrm{~cm})$. 
experiments were initiated $\left(T_{0}\right)$ after a bloom was formed ( $3 \mathrm{~h}$ since Trichodesmium addition), defined as $>95 \%$ of the cells in the water column above $0.5 \mathrm{~cm}$. To minimize bacterial contamination, the water column system was cleaned and disinfected with $10 \% \mathrm{HCl}$ for $3-5 \mathrm{~h}$ prior to each run.

\section{RNA extraction}

Surface filaments $(10 \mathrm{ml})$ were collected onto 25-mm diameter, $5-\mu \mathrm{m}$ pore-size polycarbonate filters placed in a 2-ml eppendorf tube and snapfrozen in liquid $\mathrm{N}_{2}$. Total RNA was extracted from Trichodesmium cells using TRIzol Reagent (Invitrogen, Life Technologies, Santa Cruz, CA, USA) followed by RNeasy mini Kit (Qiagen, Valencia, CA, USA). DNase (Turbo DNase, Ambion, Life Technologies) was used to any gDNA contamination from the RNA sample and RNeasy MinElute Cleanup Kit (Qiagen) to concentrate and clean the samples. Total RNA concentration was determined using a NanoDrop ND-1000 Spectrophotometer (peqLab Biotechnologie, Erlangen, Germany). First-strand complementary DNA was generated from total RNA by reverse transcription using SuperScript III First-Strand Synthesis System (Invitrogen Life Technologies). Reverse transcription reactions used equal total amounts (500 ng) of RNA and were primed with random hexamers, allowing the investigation of multiple candidate genes from the same source firststrand complementary DNA.

\section{Quantitative real-time polymerase chain reaction (qRT-PCR)}

Specific oligonucleotide DNA primer sets were designed as metacaspase 2 and 9 genes (MC2 (NCBI Accession no. YP_722351) and MC9 (NCBI Accession no. YP_724070; Table 1) (Berman-Frank et al., 2004). Expression levels of target genes (TG; metacaspase and iron stress-inducible genes) were normalized to $16 \mathrm{~S}$ rRNA housekeeping gene (HK) and calibrated to an initial time point (Table 1). Triplicate first-strand complementary DNA aliquots from each sample served as templates in real-time PCR. Reactions containing either 'no template'
(NTC) or DNase-treated RNA (to exclude genomic DNA contamination) as template served as negative controls. All NTC and RNA-only samples were always below the detection limit. Brilliant II QPCR Reagents (Stratagene, La Jolla, CA, USA) for in situ monitoring of PCR progression. Reaction mixture (total of $10 \mu \mathrm{l}$ ) contained $4 \mu \mathrm{l}$ diluted complementary DNA ( $\sim 20$ ng RNA), $5 \mu$ l SYBRgreen (Brilliant II QPCR Reagents, Stratagene), $0.5 \mu \mathrm{l}$ per primer (250 nM) and $0.5 \mu \mathrm{l}$ DEPC water. Transcript levels were determined by Corbett 6000 Rotor-Gene Q realtime PCR cycler using Brilliant SYBR Green (Brilliant II QPCR Reagents, Stratagene). Q-RT-PCRrunning conditions were: $7 \mathrm{~min}$ in $95^{\circ} \mathrm{C}$ followed by 45 cycles of $10 \mathrm{~s}$ in $95^{\circ} \mathrm{C}, 30 \mathrm{~s}$ in $60^{\circ} \mathrm{C}$ and $20 \mathrm{~s}$ in $72{ }^{\circ} \mathrm{C}$ ending in melting, $72{ }^{\circ} \mathrm{C}-95^{\circ} \mathrm{C}\left(1{ }^{\circ} \mathrm{C}\right.$ steps $)$. Samples were then analyzed by Rotor-Gene Q software subjected to the CT method Statistics (Stratagene). Standard curves were generated using serially diluted linear plasmid DNA that contained each gene amplicon (Bidle and Bender, 2008) with measured amplification efficiencies being between $88 \%$ and $93 \%$. Melt curves were performed with one distinct peak for both metacaspase and $16 \mathrm{~S}$ primers, whereas a small second peak was also apparent for the $\mathrm{IsiB}_{\text {Tery }}$ primer set (Supplementary Figure S2). The copy numbers of $\mathrm{TG}$ relative to housekeeping genes (HK) were estimated as $2^{[-1(C \mathrm{tHK}-\mathrm{CtTG})]}$ (shorthand as $2^{(-\Delta \Delta C \mathrm{t})}$ ) according to Pfaffl (2001).

\section{Measurements of caspase activity}

Surface filaments $(15 \mathrm{ml})$ were collected onto $25-\mathrm{mm}$ diameter, $5-\mu \mathrm{M}$ pore-size polycarbonate filters, placed in a 2-ml eppendorf tube and snap-frozen in liquid N. Cells were resuspended in Lauber buffer (50 mm HEPES (pH 7.3), $100 \mathrm{~mm} \mathrm{NaCl,} \mathrm{10 \%} \mathrm{sucrose,}$ $0.1 \% 3$-[(3- cholamidopropyl)-dimethylammonio]-1 propanesulfonate and $10 \mathrm{~mm}$ dithiothreitol) and sonicated on ice (four times, each for a $30 \mathrm{~S}$ cycle) using an ultracell disruptor (Sonic Dismembrator, Fisher Scientific, Waltham, MA, USA). Cell extracts were centrifuged then $(10000 \mathrm{~g}, 2 \mathrm{~min})$, and supernatant was collected for caspase activity and protein assays. Caspase-specific activity was determined

Table 1 Primer sequences used for qRT-PCR and gene expression of biomolecular markers for T. erythraeum Fe stress and the associated programmed cell death during bloom determination

\begin{tabular}{|c|c|c|c|c|}
\hline Primer ID & Sequence & Amplicon size $(b p)$ & Gene ID & Reference \\
\hline$M C 2 F$ & 5'-TAATGCGGCTCAAGGTCCTGATGA-3' & 249 & Metacaspase; PCD genetic marker & This study \\
\hline$M C 2 R$ & $3^{\prime}$-TCCGACTTTGGTTTCGACCTTCCT-5' & & & \\
\hline$M C 9 F$ & $5^{\prime}$-ACCGGCGAAATTAGTGGGTATGGA-3' & 211 & Metacaspase; PCD genetic marker & This study \\
\hline$M C 9 R$ & $3^{\prime}$-TCGCTTCGTCAAAGCACCCTCTAT-5' & & & \\
\hline$I s i B_{\text {Tery }} F$ & $5^{\prime}$-AAAGTGACTGGAGTGGTTTC- $3^{\prime}$ & 163 & Iron stress-induced protein & Chappell and Webb, 2010 \\
\hline$I_{s i B} B_{\text {Tery }} R$ & $3^{\prime}$-GTAGTACCTCCAAGCCCA5' & & & \\
\hline $16 S F$ & 5'-GGTAATACGGAGGAGGCAAGCGTTAT-3' & 117 & Small subunit ribosomal RNA; HK & This study \\
\hline $16 S R$ & 3'-TAGTTTCCACTGCCTGACCAGAGTTG-5' & & & \\
\hline
\end{tabular}

Abbreviations: Fe, iron; HK, housekeeping gene.

Tm: $55-60{ }^{\circ} \mathrm{C}$. 
using the fluorogenic, peptide substrate IETD-AFC (Calbiochem, Rockland, MA, USA) at a $50 \mathrm{~mm}$ final concentration. Kinetic analysis was performed on substrate cleavage over a 4 -h period at $26^{\circ} \mathrm{C}$ with measurements taken at $15 \mathrm{~min}$ intervals using a Fluoroskan Ascent Fl (Labsystems, Waltham, MA, USA) plate reader (Ex $405 \mathrm{~nm}, \mathrm{Em} 485 \mathrm{~nm}$ ). Cleavage rates were normalized to total protein, as determined by BCA Protein Assay (Thermo Scientific, Rockford, IL, USA).

\section{Cell measurements}

Cells were counted using a Sedgwick-Rafter Cell (Pyser-SGI, Kent, UK) and a light microscope (Nikon, Melville, NY, USA; Eclipse 80i). Filament number and size were counted using Nikon plan fluor $\times 4 / 0.75$ lens and cell length was measured by Nikon plan fluor X40/0.75 lens. Image analyses were done using Image J software (http://rsbweb. nih.gov). Trichodesmium cells are usually cylindrical, therefore, cell volume of the cylinder (length $\times \pi \times r^{2}$ ) was calculated accordingly: Trichodesmium cell length $\times \pi \times\left(1 /{ }_{2} \times\right.$ the cell width $)^{2}$. Cellular $\mathrm{C}$ content was determined according to the equation $C=0.433 \cdot \mathrm{V}^{0.863}$ (Verity et al., 1992) as, where $C$ represents cell C content $\left(C_{\text {cell }}, \mathrm{pg}\right)$ and $\mathrm{V}$ represents cell volume $\left(\mu \mathrm{M}^{3}\right)$.

\section{Chlorophyll a concentrations}

Filaments were collected on GF/F filters (Whatman, Kent, UK) and Chl $a$ was extracted by boiling for 6 min in 90\% methanol. Pigment concentration was analyzed spectrophotometrically at 664 and $750 \mathrm{~nm}$ (CARY100, Varian, Santa Clara, CA, USA) according to Tandeau de Marsac and Houmard (1988).

\section{Particulate organic $C$}

Samples $(50 \mathrm{ml})$ were filtered through precombusted ( $4 \mathrm{~h}, 450^{\circ} \mathrm{C}$ ) GF/F filters, dried overnight at $60{ }^{\circ} \mathrm{C}$ and stored in a desiccator until further analysis. POC was determined using a CHN analyzer Perkin Elmer (Waltham, MA, USA) CHNS/O elemental analyzer, PE 2400, after carbonate removal from the filters using overnight fuming with concentrated $\mathrm{HCl}$ vapor.

\section{Dissolved organic $C$}

Duplicate water samples $(40 \mathrm{ml})$ were first prefiltered through combusted GF/F filters to remove particulates and collected in acid-washed glass tubes. HCl $(37 \%)$ was added $(40 \mu \mathrm{l})$ to each sample and stored at $4{ }^{\circ} \mathrm{C}$ until analysis by TOC analyzer (Shimadzu ASI-L Autosampler, Columbia, MD, USA). TOC was determined as POC + DOC.

\section{TEP determination}

Water samples $(20 \mathrm{ml})$ were filtered gently $(\sim 100-$ 150 mbar) onto $0.4-\mu \mathrm{m}$ polycarbonate filters and TEP concentrations ( $\mu \mathrm{g}$ gum xanthan equivalents $\mathrm{l}^{-1}$ ) were measured according to Passow and Alldredge (1995). A conversion factor of 0.51 was employed to convert from milligrams of gum xanthan equivalents to milligrams of C (Engel and Passow, 2001).

\section{Results and discussion}

Formation of Trichodesmium surface bloom We experimentally induced T. erythraeum IMS101 blooms (Figure 1, Supplementary Figure S1) by introducing a dense culture $\left(3 \times 10^{6}\right.$ cells $\left.^{-1}\right)$ into an Fe-free water column. Immediately after addition, the trichomes were uniformly distributed $\left(1 \times 10^{6}\right.$ $2 \times 10^{7} l^{-1}$ ) throughout the upper $100 \mathrm{~cm}$ (Figure 2a). The customized water column was operated without turbulence, at an uniform temperature $\left(26^{\circ} \mathrm{C}\right)$, darkened from all sides and illuminated from the surface by $\sim 600 \mu \mathrm{Mol}$ quanta $\mathrm{m}^{-2} \mathrm{~s}^{-1}(12: 12 \mathrm{~h}$ light/ dark). Bloom initiation always followed cell aggregation from single trichome morphology into puff and tuft colony formation (Figure 2b). An extremely

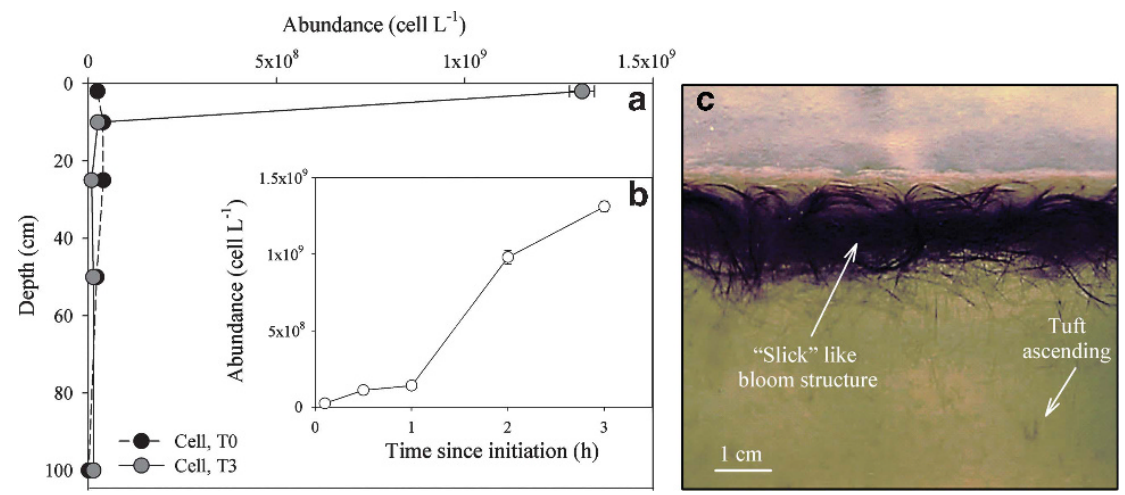

Figure 2 Dynamics of Trichodesmium bloom formation in our fabricated water column. (a) Depth (surface, 10, 25, 50 and 100 cm) measurements of cell abundance immediately after batch culture addition $\left(T_{0}\right)$ and after the establishment of an aggregated bloom $\left(T_{3 \mathrm{~h}}\right)$. (b) Surface cell abundance during $3 \mathrm{~h}$ of bloom development, along with a representative image (c) taken after the bloom was fully developed $\left(T_{3 \mathrm{~h}}\right)$. 
dense $\left(1.3 \times 10^{9} \pm 3.3 \times 10^{7} l^{-1}\right)$ 'slick'-like bloom developed at the surface (upper $0.5 \mathrm{~cm}$ ) from these ascending and aggregated colonies at a rate of $4 \times 10^{8} \mathrm{cells} \mathrm{h}^{-1}$ (Figure 2c). Integrated cell abundance remained constant $\left(3 \times 10^{8} \pm 9 \times 10^{7} \mathrm{~m}^{-3}\right)$ in the water column throughout bloom development simulations, whereas surface cell numbers increased rapidly, indicating that active ascent was due to positively buoyant cells. After $\sim 3 \mathrm{~h}, 96-98 \%$ of the cells had concentrated at the surface, incorporating significant concentrations of TOC and total organic $\mathrm{N}\left(0.72 \pm 0.09 \mathrm{mg} \mathrm{Cm}^{-2}\right.$ and $0.13 \pm 0.03 \mathrm{mg} \mathrm{N} \mathrm{m}^{-2}$, respectively), whereas $<2 \%$ of the cells were evenly distributed below the upper $0.5 \mathrm{~cm}$ throughout the rest of the water column (Figure 2a).

Although artificially expedited using dense batch cultures (Figure 1), bloom formation in our water column possessed notable similarities to natural blooms observed in tropical oceans, where surface slicks of dense Trichodesmium aggregations develop under calm conditions with sea surface temperatures of $\pm 26^{\circ} \mathrm{C}$, high solar irradiance and high concentrations of $\mathrm{Fe}$ and $\mathrm{P}$ (Karl et al., 2002; Rodier and Le Borgne, 2008, 2010; Bergman et al., 2012). In these oceanic blooms, the vertical ascent of Trichodesmium cells due to positive buoyancy (Villareal and Carpenter, 2003; Rodier and Le Borgne, 2008, 2010) occurs simultaneously with rapid growth rates, both processes accounting for the hastened, ultra-dense accumulation of cells at the surface (Rodier and Le Borgne, 2008, 2010; Bergman et al., 2012).

\section{Abrupt and synchronized bloom demise}

Once surface blooms were established, we utilized the expression levels of isiB, an archetypical prokaryotic iron stress-response protein, as a diagnostic indicator of Fe stress (Chappell and Webb, 2010), along with the levels of metacaspase gene expression (Berman-Frank et al., 2004; Bidle and Falkowski, 2004) and caspase-like catalytic activity (Berman-Frank et al., 2004, 2007) as diagnostic subcellular markers of PCD (see Materials and methods). Whereas cell numbers remained stable in our experimental water column during the first $24 \mathrm{~h}\left(T_{1 \mathrm{~d}}\right)$ of $\mathrm{Fe}$ limitation, slight increases in transcript expression levels of isiB, MC2 and MC9 genes (by 0.5-0.9 $\log ^{\Delta \Delta C t}$ ) were already detectable (Table 1, Figures 3a and b). After 2 days $\left(T_{2 \mathrm{~d}}\right)$ of Fe limitation, the expression levels of isiB, MC2 and MC9 genes increased significantly with respect to $T_{1}$ (three-, six- and five-fold, respectively) (Figure 3b). The changes in $M C$ gene expression were paralleled by 26 -fold higher caspase activity rates (718 $\pm 268 \mathrm{RFU}$ mg per protein $\mathrm{h}^{-1}$, Figure $3 \mathrm{~b}$ ).

In the aquatic environment, natural populations of Trichodesmium encounter similar Fe limitation where they can mobilize and reincorporate Fe from intracellular storages, such as 'DNA-binding proteins from starved cells', to meet cellular demands for growth (Castruita et al., 2007). The observed lag
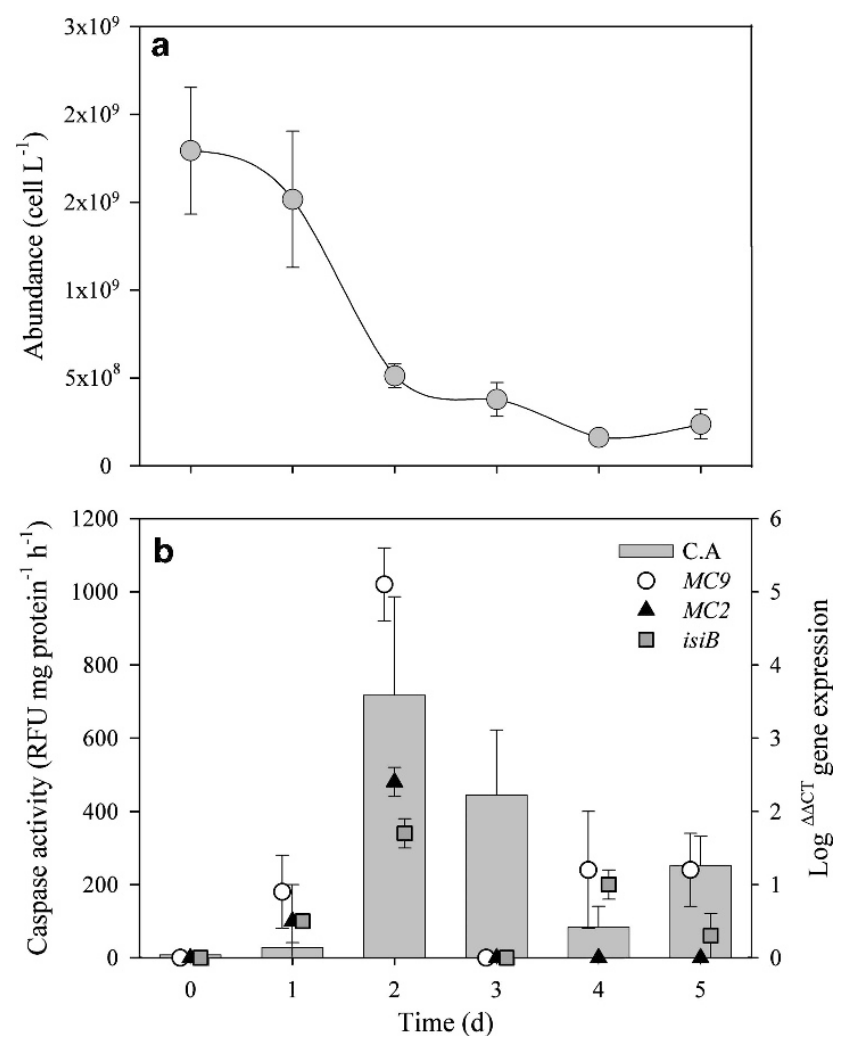

Figure 3 (a) Daily changes in the abundance of Trichodesmium cells from the induction of $\mathrm{Fe}$ stress after bloom initiation to the biomass crash after 5 days. (b) Associated changes in various biomolecular PCD markers, including caspase catalytic activity (C.A.) and the expression of selected metacaspase genes (MC2 and MC9). Expression of a known Trichodesmium Fe-stress responsive gene $(i s i B)$ was used to confirm subcellular Fe stress.

time in our system (with no changes in cell abundance; Figure 3a) between bloom initiation $\left(T_{0}\right)$ and the induction of PCD $\left(T_{2 \mathrm{~d}}\right)$ may have resulted from the consistent slow release of intracellular Fe (Castruita et al., 2007) prior to the PCD-induced collapse. Following bloom collapse $\left(T_{3 \mathrm{~d}}\right), M C$ gene expression and caspase activity rates were significantly reduced from their maximal levels $\left(T_{2 \mathrm{~d}}\right)$ by $76-100 \%$ and $40-80 \%$, respectively (Figure $3 \mathrm{~b}$ ). The low metacaspase expression and caspase-specific activity levels measured in the remaining surface trichomes were consistent with the low constitutive levels of these genes and protein activities, respectively.

These observations demonstrate that an Fe-stress induced, PCD cellular response mechanistically triggered an abrupt, synchronized Trichodesmium bloom collapse. The drastic reduction (by 71\%) in cell abundance (Figure 3a) was characterized by a notable loss of recognizable trichome cellular structure and the transition to green amorphous aggregates composed of dying and decomposing biomass (Figure 3a, Supplementary movie S1). We suggest that the remaining $29 \%\left(5.1 \times 10^{8}\right.$ cells $\left.^{-1}\right)$ of the biomass helped to ensure the survival of the Trichodesmium population. 
In different species, cysts, spores and hormogonia cells are known to be resistant to environmental stress and may also resist PCD, thus forming an inoculum for subsequent blooms (Vardi et al., 1999). Careful examination of microscopic cell images $(\sim 100$ of $\times 40$ magnification) showed sporadic short filaments during and after the crash, although these could not be definitively characterized as hormogonia. Thus, the surviving trichomes probably avoided PCD through an as yet unknown mechanism(s).

The subcellular triggers, signal transduction and regulatory networks of PCD in Trichodesmium are currently unknown. One intriguing aspect of this PCD response is the potential role that quorum sensing (QS) may have in triggering its onset. QS is known to regulate the cell-cell communication and population response through the activation of different metabolic pathways including cell death (Dandekar et al., 2012), and QS has been recently documented to control phosphorus acquisition among Trichodesmium-epibiont consortia (Hewson et al., 2009b; Hmelo et al., 2012). Further investigation is needed to identify whether QS has any role in the PCD of Trichodesmium.

\section{Linking PCD-induced bloom demise to particulate $C$} and $N$ sequestration

Our experimental water column enabled us to establish a novel mechanistic link between the PCDinduced bloom collapse and quantitative C:N export fluxes. Given this laboratory model system lacks some of the complex abiotic (physical and chemical) and biotic (microbial remineralization) interactions within a natural water column, it provides a 'best case scenario' for flux measurements upon Trichodesmium bloom collapse and, therefore, provides an useful constraint for future modeling efforts. During bloom initiation, TOC was predominantly incorporated within the Trichodesmium surface bloom (TOC/ $C_{\text {cell }}=1, \quad 0.74 \pm 0.09 \mathrm{mg} \mathrm{Nm}^{-2}$ ) and was comprised mostly of POC (Figures 4a and b, Table 2). PON concentrations were $0.13 \pm 0.04 \mathrm{mg} \mathrm{N} \mathrm{m}^{-2}$ and POC/ PON was $6.4 \pm 1$. TEP comprised a very small component (only 10\%) of the TOC pool (Table 2) and DOC was below the analytical detection limits. TEPs are present in large numbers in all aquatic environments and regarded as part of the POC pool (Passow, 2002). They are intensely sticky organic microgels that promote aggregation and may act as a bridge between dissolved and particulate matter (Passow, 2002).

Abrupt bloom collapse $\left(T_{2 \mathrm{~d}}\right)$ from Fe-stressinduced PCD was characterized by a drastic reduction in $C_{\text {cell }}(87 \%)$ and removal rates of $11-17 \mu \mathrm{g}$ $\mathrm{Cm}^{-2} \mathrm{~h}^{-1}$, as well as a dramatic increase (2.2-fold) in TEP production, which resulted in two-threefold increases in TEP/TOC and TOC/ $C_{\text {cell }}$, respectively (Table 3, Figures 4a-c). Similar to the oceanic milieu (Passow, 2002; Bar-Zeev et al., 2011) and our earlier study (Berman-Frank et al., 2007), these
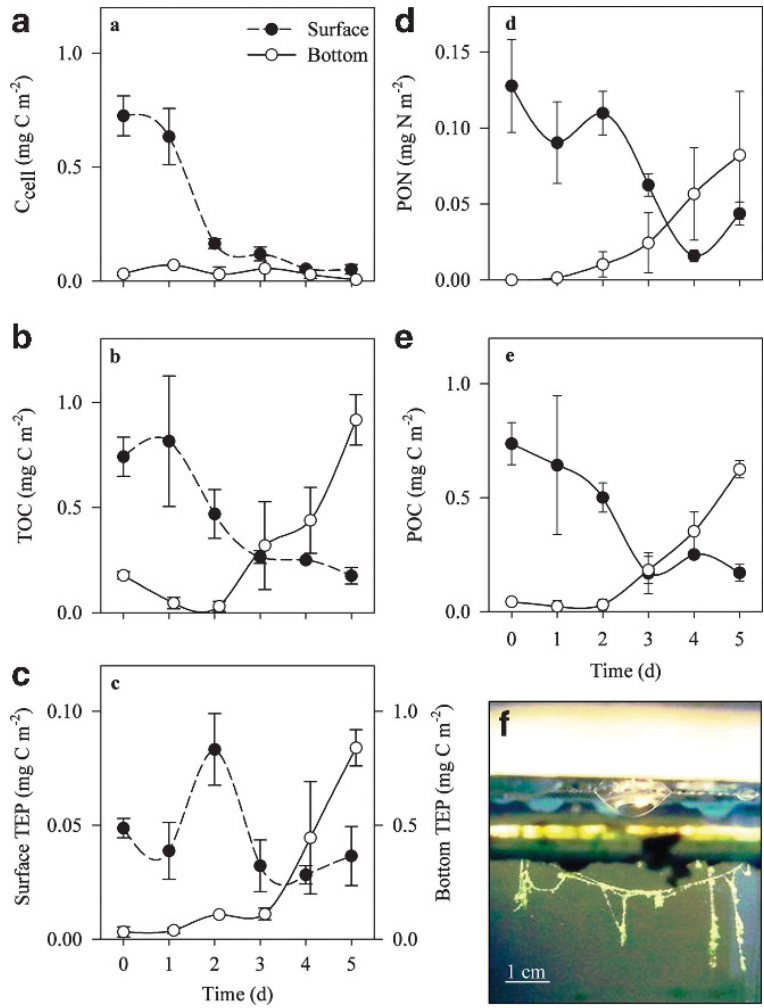

Figure 4 Temporal changes in organic carbon and nitrogen in the surface bloom and exported material at the bottom of the water column during 5 days of $\mathrm{Fe}$ stress. (a) Calculated Trichodesmium cell carbon content, $C_{\text {cell }}$ (see Materials and methods) along with (b) TOC, (c) carbon content associated with TEP (note scales), and (d and e) PON and POC, respectively. (f) A corresponding image highlighting the fate of the surface bloom following 2 days of induced Fe stress. Note the difference in scales for TEP and PON associated with surface and bottom locations.

Table 2 Temporal changes in the relative composition (w/w) and distribution of organic carbon and nitrogen fractions within the water column during the 5 days from bloom induction to biomass crash

\begin{tabular}{|c|c|c|c|c|c|c|}
\hline & Time & $\begin{array}{c}\text { TOC/ } \mathrm{C}_{\text {cell }} \\
(w / w)\end{array}$ & $\begin{array}{c}P O C / T O C \\
(w / w)\end{array}$ & $\begin{array}{c}\text { DOC/TOC } \\
(w / w)\end{array}$ & $\begin{array}{c}\text { TEP/TOC } \\
(w / w)\end{array}$ & $\begin{array}{c}P O C / P O N \\
(w / w)\end{array}$ \\
\hline \multirow{6}{*}{ Surface (bloom) } & 0 & 1.0 & 1 & 0.00 & 0.1 & 5.8 \\
\hline & 1 & 1.3 & 0.8 & 0.00 & 0.05 & 7.1 \\
\hline & $2(\mathrm{BC})$ & 2.9 & 1.1 & 0.00 & 0.2 & 4.6 \\
\hline & 3 & 2.2 & 0.6 & 0.01 & 0.1 & 2.7 \\
\hline & 4 & 4.7 & 1.0 & 0.00 & 0.1 & ND \\
\hline & 5 & 3.4 & 1.0 & 0.01 & 0.2 & 3.9 \\
\hline \multirow[t]{6}{*}{ Bottom } & 0 & 5.7 & 0.2 & 0.00 & 0.2 & $U D L$ \\
\hline & 1 & 0.3 & 0.9 & 0.00 & 0.8 & UDL \\
\hline & 2 (BC) & 1.0 & 1.0 & 0.00 & ND & 2.9 \\
\hline & 3 & 5.9 & 0.6 & 0.20 & 0.3 & 7.5 \\
\hline & 4 & 13 & 1 & 0.22 & 1 & 6.2 \\
\hline & 5 & 149 & 0.7 & 0.09 & 0.9 & 7.6 \\
\hline
\end{tabular}

Abbreviations: BC, bloom collapse; DOC, dissolved organic C; ND, no data; POC, particulate organic C; PON, particulate organic N; TEP, transparent exopolymeric particle; TOC, total organic C; UDL, under detection limit.

increased ratios reflect the cessation of active incorporation of organic $\mathrm{C}$ and $\mathrm{N}$ into Trichodesmium cells and its preferential excretion into the media as polysaccharides and detrital matter. Moreover, it led to greatly enhanced sinking rates of 
Table 3 Daily changes in the removal rates of surface $(0.5 \mathrm{~cm})$ Trichodesmium bloom cell biomass and sinking rates measured at the bottom $(200 \mathrm{~cm})$ during the 5 experimental days

\begin{tabular}{|c|c|c|c|c|c|}
\hline \multirow[t]{2}{*}{ Time (day) } & \multicolumn{2}{|c|}{$\begin{array}{c}\text { Removal } \\
\text { (mg C per day) }\end{array}$} & \multicolumn{3}{|c|}{$\begin{array}{c}\text { Sinking rate } \mu g \\
(C \text { or } N) \mathrm{m}^{-1} \text { per day }\end{array}$} \\
\hline & $\mathrm{C}_{\text {cell }}$ & TOC & POC & TEP & $P O N$ \\
\hline 0 & 0 & 0 & 0 & 0 & 0 \\
\hline 1 & $11 \pm 4$ & 0 & 0 & $0 \pm 0.1$ & 0 \\
\hline 2 (BC) & $17 \pm 8$ & $0.6 \pm 0.8$ & $0.6 \pm 0.8$ & $0.8 \pm 0.1$ & $0.2 \pm 0.2$ \\
\hline 3 & $4 \pm 2$ & $5.4 \pm 1.1$ & $2.4 \pm 1.6$ & $0.1 \pm 0.2$ & $0.4 \pm 0.2$ \\
\hline 4 & $2 \pm 1$ & $5.5 \pm 2.3$ & $4.0 \pm 0.3$ & $5.2 \pm 3.9$ & $0.5 \pm 0.8$ \\
\hline 5 & $0 \pm 0.1$ & $6.5 \pm 2.6$ & $5.7 \pm 2$ & $0.5 \pm 0.8$ & $0.7 \pm 0.1$ \\
\hline
\end{tabular}

Abbreviations: BC, bloom collapse; C, carbon; N, nitrogen; POC, particulate organic C; PON, particulate organic N; TEP, transparent exopolymeric particle; TOC, total organic $\mathrm{C}$

Removal rates were calculated as $\left(T_{\mathrm{n}}-T_{\mathrm{n}-1}\right) / 24 \mathrm{~h}$, whereas sinking rates were determined as $\left[\left(T_{n}-T_{n-1}\right) / 24 h\right] / 2 \mathrm{~m}$.

captured aggregates, likely resulting from TEP scaffolding (De La Rocha and Passow, 2007) of Trichodesmium detrital matter, documented as large $(\sim 1-5 \mathrm{~mm})$ greenish aggregates (Figure $4 \mathrm{f})$. Twenty-four hours after the bloom collapse $\left(T_{3 \mathrm{~d}}\right)$, we quantified the sinking velocities of these aggregates at $\sim 200 \mathrm{~m}$ per day (Supplementary movie S1). Sinking rates of the corresponding TOC (composed mainly from POC) also increased significantly $\left(5.4 \pm 1.1 \mu \mathrm{g} \mathrm{C} \mathrm{m} \mathrm{h}^{-1}\right.$, Table 3, Supplementary movie $\mathrm{S} 1$ ) at this time ( $\left.T_{3 \mathrm{~d}}\right)$ and rapidly accumulated at the bottom of the column $\left(0.32 \pm 0.21 \mathrm{mg} \mathrm{C} \mathrm{m}^{-2}\right)$. While organic $\mathrm{C}$ and $\mathrm{N}$ rapidly sank and accumulated at the chamber bottom at $T_{3 \mathrm{~d}}$, maximal TEP sinking rates $\left(5.2 \pm 3.9 \mu \mathrm{g} \mathrm{C} \mathrm{m} \mathrm{h}{ }^{-1}\right)$ were measured $24 \mathrm{~h}$ later $\left(T_{4 \mathrm{~d}}\right)$. We suggest that the temporal uncoupling between the maximal TOC and TEP sinking rates ( $T_{3 \mathrm{~d}}$ vs $T_{4 \mathrm{~d}}$, respectively) may originate from their differential densities and viscosities (De La Rocha and Passow, 2007). Nevertheless, 5 days $\left(T_{5}\right)$ after bloom initiation, cell abundance, organic $\mathrm{C}$ and $\mathrm{N}$ concentrations at the surface layer of the column were drastically reduced, having been efficiently exported to the bottom of the 2-m water column (Figure 4, Table 3). Notably, TOC measured at the bottom $\left(0.9 \pm 0.1 \mathrm{mg} \mathrm{Cm}^{-2}\right)$ was predominantly composed of POC (68\%), with DOC accounting for only $12 \%$ (Figure 4 , Table 2). Likewise, TEP accounted for as much as $90 \%$ of the TOC $\left(0.84 \pm 0.1 \mathrm{mg} \mathrm{C} \mathrm{m}^{-2}\right)$. PON-measured concentrations were $0.1 \pm 0.04 \mathrm{mg} \mathrm{N} \mathrm{m}^{-2}$ and C: $\mathrm{N}$ ratio increased to 7.6 (Figure 4, Table 2).

The mechanistic link between PCD cellular processes and associated pulses of C:N export underscores its fundamental role in regulating cell fate, particle flux, and upper ocean biogeochemistry of bloom-forming diazotrophs. Although export fluxes from natural Trichodesmium or other diazotrophic blooms are poorly defined (Mulholland, 2007; Bergman et al., 2012), newly fixed particulate organic matter (POM) in the pelagic surface oceans is the primary source for exported $\mathrm{C}$ and $\mathrm{N}$ to the deep ocean (Buesseler et al., 2007; Arístegui et al., 2009). Globally, the export efficiency of POM from surface waters via the biological pump varies considerably (from 2 to $50 \%$ ), with up to a quarter of this material sinking below $1000 \mathrm{~m}$ (Boyd and Trull, 2007), depending on the magnitude of net primary production, sinking velocities and remineralization rates (Boyd and Trull, 2007; De La Rocha and Passow, 2007).

Heterotrophic bacteria have a significant role in decomposing and remineralizing POC, PON and TEP as part of the microbial loop (Passow, 2002; Azam and Malfatti, 2007; Arístegui et al., 2009; Bar-Zeev et al., 2011; Yamada et al., 2012), resulting in particle solubilization, stoichiometric transformations and changes in export fluxes (Cho and Azam, 1988; Smith et al., 1992; Schneider et al., 2003; Boyd and Trull, 2007). Heterotrophic bacteria were recently shown to have an active role in gene transcription as epibionts within the Trichodesmium consortia and are suggested to alter the Trichodesmium metabolism (Hewson et al., 2009b). Our experimental observations represent a contrasting 'best case scenario', whereby algal bloom, crash and subsequent vertical flux were largely isolated from these aforementioned microbial transformation processes and, consequently, provide an upper limit of potential vertical $\mathrm{C}$ and $\mathrm{N}$ fluxes following Trichodesmium bloom crashes.

Sinking velocities are governed by particle concentration (McDonnell and Buesseler, 2010), size (following Stokes law) and density (Arístegui et al., 2009). Our experimental water column simulations highlight that rapid development and abrupt, PCD-induced collapse of Trichodesmium blooms will serve to mechanistically enhance these firstorder controls on particle flux. Bloom collapse via PCD commences with the internal degradation of cellular components (such as gas vesicles, Berman-Frank et al., 2004) and is coincident with the massive TEP production. The resulting high concentration of dense, detrital particulate matter coupled with the sticky nature of TEP serves to promote the formation of large aggregates (De La Rocha and Passow, 2007; Burd and Jackson, 2009; McDonnell and Buesseler, 2010) and preserves C and $\mathrm{N}$ in particulate forms through a prompt downward pulse of POM (Supplementary movie S1). Moreover, we suggest that the toxicity of Trichodesmium and low palatability to grazers (Rodier and Le Borgne, 2008; Kerbrat et al., 2011) combined with the sheer magnitude of POM export flux will critically limit the amount of recycled matter within the upper mixed layer.

Although the sinking rates and degree of export preservation in our model system cannot $a$ priori be extrapolated to the ocean, our findings provide novel mechanistic context for recent observations of massive, localized Trichodesmium bloom collapses $\left(6 \mu \mathrm{g} \mathrm{Cl}^{-1}\right.$ per day and $42 \mathrm{ng} \mathrm{N} \mathrm{l}^{-1}$ per 
day, Rodier and Le Borgne, 2008, 2010) and reported vertical fluxes of newly fixed POC and PON from diazotrophs (17 $\mu \mathrm{g} \mathrm{Cm}^{-2}$ per day and $1.1 \mu \mathrm{g} \mathrm{N} \mathrm{m} \mathrm{N}^{-2}$ per day, Karl et al., 2012). Indeed, the tight link between PCD and C:N export pulses (demonstrated here) highlights the fundamental influence that PCD may exert on the oceanic biogeochemical cycling associated with bloom-forming natural populations. Parameterizations for the effects of PCD-mediated bloom collapse should be included into future diagnostic models to constrain the relative POC and PON fluxes from diazotrophs in the modern ocean.

\section{Conflict of Interest}

The authors declare no conflict of interest.

\section{Acknowledgements}

We would like to thank Mr Shimon Pilo for technical assistance and the Bar-Ilan University Mechanical Workshop for constructing the experimental water column. We would like to thank Mr Gad Rosenberg and Dr Sarit Lampert for designing the $16 S$ rRNA HK primers. This research was supported by grants from the United States-Israel Binational Science Foundation (BSF; Grant no. 2008048) to IB-F and KDB and from the United States National Science Foundation (OCE-1061883) to KDB, as well as an MSc scholarship to IA by the Mina and Everard Goodman Faculty of Life Sciences, Bar-Ilan University.

\section{Disclaimer}

The data in this manuscript are all original and have not been submitted elsewhere for consideration.

\section{References}

Azam F, Malfatti F. (2007). Microbial structuring of marine ecosystems. Nat Rev Microbiol 5: 782-791.

Arístegui J, Gasol JM, Duarte CM, Herndl GJ. (2009). Microbial oceanography of the dark ocean's pelagic realm. Limnol Oceanogr 54: 1501-1529.

Banks J. (1770). The Endeavour Journal of Sir Joseph Banks. Captain James Cook daily Journal, Vol. 1, http://southseas.nla.gov.au/journals/cook/17700828.

Bar-Zeev E, Berman T, Rahav E, Dishon G, Herut B, Kress N et al. (2011). Transparent exopolymer particle (TEP) dynamics in the eastern Mediterranean Sea. Mar Ecol Prog Ser 431: 107-118.

Bergman B, Sandh G, Lin S, Larsson J, Carpenter EJ. (2012). Trichodesmium-a widespread marine cyanobacterium with unusual nitrogen fixation properties. FEMS Microbiol Rev 37: 286-302.

Berman-Frank I, Bidle KD, Haramaty L, Falkowski PG. (2004). The demise of the marine cyanobacterium, Trichodesmium spp., via an autocatalyzed cell death pathway. Limnol Oceanogr 49: 997-1005.

Berman-Frank I, Rosenberg G, Levitan O, Haramaty L, Mari X. (2007). Coupling between autocatalytic cell death and transparent exopolymeric particle production in the marine cyanobacterium Trichodesmium. Environ Microbiol 9: 1415-1422.

Bidle KD, Falkowski PG. (2004). Cell death in planktonic photosynthetic microorganisms. Nat Rev Microbiol 2: 643-655.

Bidle KD, Bender SJ. (2008). Iron starvation and culture age activate metacaspases and programmed cell death in the marine diatom, Thalassiosira pseudonana. Eukaryot Cell 7: 223-236.

Boyd PW, Trull TW. (2007). Understanding the export of biogenic particles in oceanic waters: is there consensus? Prog Oceanogr 72: 276-312.

Buesseler KO, Lamborg CH, Boyd PW, Lam PJ, Trull TW, Bidigare RR et al. (2007). the Ocean's twilight zone. Science 316: 567-570.

Burd BA, Jackson AG. (2009). Particle aggregation. Annu Rev Mar Sci 1: 65-90.

Capone DG, Subramaniam A, Montoya JP, Voss M, Humborg C, Johansen AM et al. (1998). An extensive bloom of the $\mathrm{N}_{2}$-fixing cyanobacterium Trichodesmium erythraeum in the central Arabian Sea. Mar Ecol Prog Ser 172: 281-292.

Castruita M, Elmegreen LA, Shaked Y, Stiefel EI, Morel FMM. (2007). Comparison of the kinetics of iron release from a marine (Trichodesmium erythraeum) Dps protein and mammalian ferritin in the presence and absence of ligands. J Inorg Biochem 101: 1686-1691.

Chappell PD, Webb E. (2010). A molecular assessment of the iron stress response in the two phylogenetic clades of Trichodesmium. Environ Microbiol 12: 13-27.

Chen YB, Zehr JP, Mellon M. (1996). Growth and nitrogen fixation of the diazotrophic filamentous nonheterocystous cyanobacterium Trichodesmium sp IMS 101 in defined media: evidence for a circadian rhythm. J Phycol 32: 916-923.

Cho BC, Azam F. (1988). Major role of bacteria in biogeochemical fluxes in the ocean's interior. Nature 332: 441-443.

Dandekar AA, Chugani S, Greenberg EP. (2012). Bacterial quorum sensing and metabolic incentives to cooperate. Science 338: 264-266.

Darwin CR. (1909). The Voyage of the Beagle Chapter I. Collier PF \& Son: New York, NY, USA, p 24.

De La Rocha CL, Passow U. (2007). Factors influencing the sinking of POC and the efficiency of the biological carbon pump. Deep Sea Res 54: 639-658.

Engel A, Passow U. (2001). Carbon and nitrogen content of transparent exopolymer particles (TEP) in relation to their Alcian Blue adsorption. Mar Ecol Prog Ser 219: 1-10.

Hmelo LR, Van Mooy BAS, Mincer TJ. (2012). Characterization of bacterial epibionts on the cyanobacterium Trichodesmium. Aquatic Microbial Ecol 67: $1-14$.

Hewson I, Govil S, Capone DG, Carpenter EJ, Fuhrman J. (2004). Evidence of Trichodesmium viral lysis and potential significance for biogeochemical cycling in the oligotrophic ocean. Aquatic Microbial Ecol 36: $1-8$.

Hewson I, Poretsky RS, Dyhrman ST, Zielinski B, White AE, Tripp HJ et al. (2009b). Microbial community gene expression within colonies of the diazotroph, Trichodesmium, from the Southwest Pacific Ocean. ISME J 3: 1286-1300.

Karl DM, Michaels A, Bergman B, Capone DG, Carpenter E, Letelier $\mathrm{R}$ et al. (2002). Dinitrogen 
fixation in the world 's oceans. Biogeochemistry 57: 47-98.

Karl DM, Church MJ, Dore JE, Letelier RM, Mahaffeyd C. (2012). Predictable and efficient carbon sequestration in the North Pacific Ocean supported by symbiotic nitrogen fixation. Proc Natl Acad Sci USA 109: 1842-1849.

Kerbrat S, Amzil Z, Pawlowiez R, Golubic S, Sibat M, Darius HT et al. (2011). First evidence of Palytoxin and 42-Hydroxy-palytoxin in the marine cyanobacterium Trichodesmium. Mar Drugs 9: 543-560.

Lugomela C, Lyimo TJ, Bryceson I, Semesi AK, Bergman B. (2002). Trichodesmium in coastal waters of Tanzania: diversity, seasonality, nitrogen and carbon fixation. Hydrobiologia 477: 1-13.

Luo Y-W, Doney SC, Anderson LA, Benavides M, Berman-Frank I, Bode A et al. (2012). Database of diazotrophs in global ocean: abundance, biomass and nitrogen fixation rates. Earth Syst Sci Data 4: 47-73.

McDonnell AMP, Buesseler OK. (2010). Variability in the average sinking velocity of marine particles. Limnol Oceanogr 55: 2085-2096.

Mulholland MR. (2007). The fate of nitrogen fixed by diazotrophs in the ocean. Biogeosciences 4: 37-51.

O’Neil JM. (1998). The colonial cyanobacterium Trichodesmium as a physical and nutritional substrate for the harpacticoid copepod Macrosetella gracilis. J Plankton Res 20: 43-59.

Passow U, Alldredge A. (1995). A dye-binding assay for the spectrophotometric measurement of transparent exopolymer particles (TEP). Limnol Oceanogr 40: 1326-1335.

Passow U. (2002). Transparent exopolymer particles (TEP) in aquatic environments. Prog Oceanogr 55: 287-333.

Pfaffl MW. (2001). A new mathematical model for relativequantification in real-time RT-PCR. Nucleic Acids Res 29: E45.

Rodier M, Le Borgne R. (2010). Population and trophic dynamics of Trichodesmium thiebautii in the SE lagoon of New Caledonia. Comparison with T. erythraeum in the SW lagoon. Mar Pollut Bull 61: 349-359.

Rodier M, Le Borgne R. (2008). Population dynamics and environmental conditions affecting Trichodesmium spp. (filamentous cyanobacteria) blooms in the south-west lagoon of New Caledonia. J Exp Mar Biol Ecol 358: 20-32.

Schneider B, Schlitzer R, Fischer G, Nöthig EM. (2003). Depth-dependent elemental compositions of particulate organic matter (POM) in the ocean. Global Biogeochem Cycles 17: 32.

Smith DC, Simon M, Alldrege AL, Azam F. (1992). Intense hydrolytic enzyme activity on marine aggregates and implications for rapid particle dissolution. Nature 359: 139-142.

Subramaniam A, Carpenter EJ, Falkowski PG. (1999). Bio-optical properties of the marine diazotrophic cyanobacteria Trichodesmium spp a reflectance model for remote-sensing. Limnol Oceanogr 44: 618-627.

Tandeau de Marsac N, Houmard J. (1988). Complementary chromatic adaptation: physiological conditions and action spectra. Methods Enzymol 167: 318-328.

Vardi A, Berman-Frank I, Rozenberg T, Hadas O, Kaplan A, Levine A. (1999). Programmed cell death of the dinoflagellate Peridinium gatunense is mediated by $\mathrm{CO}_{2}$ limitation and oxidative stress. Curr Biol 9: 1061-1064.

Verdugo P, Santschi HP. (2010). Polymer dynamics of DOC networks and gel formation in seawater. Deep Sea Res 57: 1486-1493.

Verity PG, Robertson CY, Tronzo CR, Andrews MG, Nelson JR, Sieracki ME. (1992). Relationships between cell volume and the carbon and nitrogen content of marine photosynthetic nanoplankton. Limnol Oceanogr 37: 1434-1446.

Villareal TA, Carpenter EJ. (2003). Buoyancy regulation and the potential for vertical migration in the oceanic cyanobacterium Trichodesmium. Microbial Ecol 45: $1-10$.

Westberry TK, Siegel DA. (2006). Spatial and temporal distribution of Trichodesmium blooms in the world's oceans. Global Biogeochem Cycles 20: GB4016.

Yamada N, Fukuda H, Ogawa H, Saito H, Suzumura M. (2012). Heterotrophic bacterial production and extracellular enzymatic activity in sinking particulate matter in the western North Pacific Ocean. Front Microbiol 3: 379.

Supplementary Information accompanies this paper on The ISME Journal website (http://www.nature.com/ismej) 